\title{
Conversionary Preaching and the Jews in Early Modern Rome
}

\author{
Emily Michelson
}

\begin{tabular}{|l|l|}
\hline Date of deposit & $30 / 08 / 2016$ \\
\hline Document version & Author's accepted manuscript \\
\hline Access rights & $\begin{array}{l}\text { C The Past and Present Society, Oxford, 2017. This work is made } \\
\text { available online in accordance with the publisher's policies. This is } \\
\text { the author created, accepted version manuscript following peer } \\
\text { review and may differ slightly from the final published version. }\end{array}$ \\
\hline $\begin{array}{l}\text { Citation for } \\
\text { published version }\end{array}$ & $\begin{array}{l}\text { Michelson, E. (2017). Conversionary preaching to the Jews of } \\
\text { Rome. Past \& Present. }\end{array}$ \\
\hline $\begin{array}{l}\text { Link to published } \\
\text { version }\end{array}$ & https://dx.doi.org/10.1093/pastj/gtx013 \\
\hline
\end{tabular}

Full metadata for this item is available in St Andrews Research

Repository at: https://research-repository.st-andrews.ac.uk/

\section{St Andrews Research Repository}




\section{Conversionary Preaching to the Jews of Rome*}

\section{$\underline{\text { Word Count }}$}

\section{Article: 10065}

\section{Notes: 4656 (+84 in acknowledgments)}

In the Vatican Archives, a manuscript diary records the daily activities of an unnamed Italian priest. When the household he served moved from Spain to Rome in the late 1570s, the diarist began to take especially careful note of the sermons he attended nearly every day of Lent. He continued the practice every year until the diary ended in $1593 .{ }^{1}$ The priest belonged to an increasingly important entourage. During the 1580s his employer, Ippolito

Aldobrandini, was elevated to the cardinalate, and later became Pope Clement VIII.

Throughout the diarist's time in Rome, his patron's rising star led him increasingly to sermons in Rome's newest or grandest churches: Chiesa Nuova, San Lorenzo in Damaso, St Peter's. Given his access to Rome's most elite courts and pulpits, why, then, did the diary author also repeatedly attend the conversionary sermons forced on the Jews of Rome?

The diarist's attraction to conversionary sermons matters, in part, because he was not alone in seeking them out. Two better-known memoirists did the same. Michel de Montaigne, who famously visited a Jewish circumcision while in Rome in 1581, also went to see an 'admirable' former rabbi combat Jewish belief from the pulpit. Gregory Martin, the English priest who immortalized public religious life in Rome, corroborates in his memoir many of the details provided by the diarist and by Montaigne. ${ }^{2}$ Conversionary sermons had a broader appeal to many Christians. They became an important and popular spectacle for Christian

\footnotetext{
. Profound thanks to those who read and commented on drafts of this article (especially Frances Andrews, Euan Cameron, Patrick O'Banion, Kathryn Rudy, Moshe Sluhovsky, and the students in my Early Modern Rome module), and to those who gave feedback on the many occasions when I have spoken on this topic. I am also grateful to my writing groups for their support, to Villa I Tatti and the Carnegie Trust for their generous research funding, and to the editors and reviewers of Past \& Present.

${ }^{1}$ Anonymous (1576-1593). 'Diario di anonimo ecclesiastico al servizio di Ippolito Aldobrandini.' Archivio Segreto Vaticano (ASV), Fondo Borghese IV, 145, 145A, 145B.

${ }^{2}$ Michel de Montaigne, The Complete Works of Montaigne: Essays, Travel Journal, Letters, trans. Donald M. Frame (London, 1958); Gregory Martin, Roma Sancta (1581), ed. George Bruner Parks (Rome, 1969).
} 
residents and visitors alike in Rome, particularly as European tourists increasingly visited ghettos, and as ethnographic interest in Jews grew. The practice was abolished in 1847, but it remains familiar today among tourists to historic Jewish sites. ${ }^{3}$ Scholars have generally considered conversionary sermons as part of the broader mission to Jews in sixteenth-century Rome. ${ }^{4}$ But the staging and delivery of the sermons indicate otherwise: that non-Jewish spectators were not incidental, and that from the outset conversionary sermons addressed Christians as well as Jews.

Recent scholarship has increasingly emphasized the notion of 'imaginary' Jews, an enduring aspect of Western European thought in which the concept of Jews or Judaism serves as a flexible category, an empty vessel into which various meanings can be poured as necessary, though always taking on a familiar shape thereby. David Nirenberg has provided one recent and forceful demonstration of the deep roots of imaginary or 'hermeneutic' Jews; he describes how the concept of Judaism has served diverse, even contradictory purposes, whether theological or political, in Western European history. ${ }^{5}$ These symbolic uses, it must

\footnotetext{
${ }^{3}$ For Catholic preachers in Jewish History, see Kenneth R. Stow, 'The Papacy and the Jews: Catholic Reformation and Beyond', Jewish History, vi (1992) and his other works. For the need to integrate conversionary preaching into Catholic history, see Marina Caffiero, Legami Pericolosi: Ebrei e cristiani tra eresia, libri proibiti e stregoneria (Turin, 2012), 272-273; For ghetto tourism see Benjamin Ravid, 'Christian Travelers in the Ghetto of Venice : Some Preliminary Observations', in Studies on the Jews of Venice, 15001800 (Aldershot, 2003), and Yaakov Deutsch, Judaism in Christian Eyes: Ethnographic Descriptions of Jews and Judaism in Early Modern Europe (Oxford and New York, 2012). For contemporary tourism, see for example the website http://www.romeinformation.it/en/rome-jewish-ghetto/ which notes, mistakenly, that 'On Saturdays, the adult members of the community had to attend the so-called compulsory preaches, sermons whose purpose was to convert them to the Christian religion; they were held by the small church of St.Gregory (now facing the huge synagogue, built in 1904) and by the tiny Carmel Temple, in via Santa Maria in Publicolis' Accessed 25 July 2016.

${ }^{4}$ For conversionary sermons, see the five linked articles on 'I predicatori Domenicani degli Ebrei' by Alberto Zucchi, Memorie Domenicane, li (1934) and 52/1 (1935); Attilio Milano, 'Un sottile tormento nella vita del ghetto di roma: La predica coattiva,' La Rassegna Mensile di Israel, xviii (1952); Renata Martano, 'La missione inutile: la predicazione obbligatoria agli ebrei nella seconda metà del cinquecento', Itinerari ebraico-cristiani: società, cultura, mito, ed. Anna Morisi Guerra (Fasano, 1987); Fiamma Satta, 'Predicatori agli ebrei, catecumeni e neofiti a Roma nella prima metà del seicento', ibid; Caffiero, Legami Pericolosi, 269-295; Martine Boiteux, 'Preaching to the Jews in Early Modern Rome: Words and Images', The Jewish-Christian Encounter in Medieval Preaching, ed. Jonathan Adams and Jussi Hanska, (New York, 2015).

${ }^{5}$ David Nirenberg, Anti-Judaism: The Western Tradition, 1st ed. (New York, 2013); Other scholarship investigating this concept across periods and disciplines includes Jeremy Cohen, Living Letters of the Law: Ideas of the Jew in Medieval Christianity (Berkeley, 1999); Eliane Glaser, Judaism without Jews: Philosemitism and Christian Polemic in Early Modern England (Basingstoke, 2007); Nina Rowe, The Jew, the Cathedral and the Medieval City: Synagoga and Ecclesia in the Thirteenth Century (Cambridge and New York, 2011); Eva Joanna Holmberg, Jews in the Early Modern English Imagination: A Scattered Nation (Farnham, 2012).
} 
be emphasized, bear only the most tenuous ties, if any, to actual Jewish communities and their history. They have proved equally expedient with or without any Jews in proximity.

This article considers how the broad category of 'imaginary Jews' fared in the spotlight of conversionary preaching in Rome. ${ }^{6}$ It expands on the scholarly argument that Judaism is a mutable and broadly trans-historical category that absorbs different connotations in different historical contexts. Nirenberg's account of this process identifies key moments in early modern Europe where Christians employed particular ideas about Jews: Luther's recasting of the Roman Church as Judaized; the mythologized importance of Judaism in Inquisition Spain after expulsion; the burdens of imagined Judaism in England's theatrical and mercantile cultures; the dependence of post-Reformation political thought on concepts of 'Judaism' and 'Israel'.

Rome, however, is a case unlike any of these. Studying it changes our concept of how imaginary Judaism functioned. Rome was not only the crucible of a newly global religion; it was also one of the few places where imagined concepts of Jews were not easily distanced from living Jews. Rome's Jewish community was the oldest and only continuous Jewish settlement in Europe: Jews in Rome predated Christians. At the same time, Rome's Holy See, over many centuries, also generated most of Europe's anti-Jewish rhetoric and theology. The early modern period brought new pressures to both Christian and Jewish Rome. Rome's Jewish population soared as it absorbed immigrants expelled from the Iberian empire, including southern Italy, in 1492 and from most of the Papal States (except Avignon and Ancona) in $1569 .{ }^{7}$ So too did the numbers of young men in Roman seminaries who dreamed of missionary glory around the world. In the wake of the Protestant threat and the Council of

\footnotetext{
${ }^{6}$ Some phrases, and some material relating to the preacher Evangelista Marcellino, appeared previously in Michelson, Emily. 'Evangelista Marcellino: One Preacher, Two Audiences.' Archivio Italiano per la Storia della pietà 25 (2012): 185-202. While the two pieces share a premise - that conversionary preaching also addressed Christians - this article represents a significant advance in my research and analysis.

${ }^{7}$ Benjamin Ravid, 'Venice, Rome, and the Reversion of New Christians to Judaism: A Study in Ragione si Stato', L'identità dissimulata: Giudaizzanti iberici nell'Europa cristiana dell'età moderna, ed. Pier Cesare Ioly Zorattini (Florence, 2000), 175.
} 
Trent, the Holy See and other religious institutions deliberately sought to cast the city as a beacon of piety, shining out over an increasingly widespread realm. Thus in the caput mundi the premier manufacturer of Judaic symbolism ('imaginary Jews') confronted Europe's oldest continuous community of living Jews. Imagined Jews and living Jews in Rome were equally robust, equally impossible to ignore, and had equal claims to antiquity.

At conversionary sermons, both categories of Jews converged. Christian anti-Jewish rhetoric, elaborated over the course of centuries, secured a physical Jewish audience in a regular, sustained, and public way for the first time. But both the context and the content of the sermons indicate that in the early years of conversionary preaching, conversion was never its only goal nor Jews its only target. Its conversionary function for Jews was subordinate to the various purposes it could serve for Christians. From the first, conversionary sermons addressed a multilayered, diverse audience, and became a key platform for affirming Catholic identity. The spectacle of conversionary preaching became one of the city's most highly charged events, a powerful emblem of the changing notions of innovation and tradition that confronted early modern Catholics in Rome.

I will identify which uses of Judaism, out of the many deployed in western European history, played best in early modern Rome. I will suggest, first, that in Rome the 'imaginary Jew' was a visual and visible as well as rhetorical category; second, that both in spectacle and in sermon, living Jews performed the role of 'imaginary Jews'; finally, that the category of 'imaginary Jews' was also understood to include Christians. While across early modern Europe Judaism could signify a wide variety of abstract concepts, in Rome Jews came to be construed, above all, as potential Christians, and as validators of Catholicism. In their perceived ability to embrace Christian values, Judaism in Rome thus served as both mirror and pillar of Catholicism - its 'other', but simultaneously, a model of piety. 
This interpretation of Judaism closely suited the needs of Counter-Reformation Rome. Its features are evident both in the arrangement of the conversionary preaching spectacle, and in the preaching rhetoric to and about Jews. An ambitious and increasingly universalist Church deployed its oldest and nearest opponents, Jews, to dramatize the possibility of choosing Catholicism. In this way, Jews modeled the ideal behavior desired of other peoples in the Counter-Reformation: Cradle Catholics embracing greater piety; Protestants of various confessions returning to Roman worship; overseas populations rewarding the efforts of Catholic missionaries.

Rome's specific use of Jews in conversionary preaching therefore also forms a useful commentary on the broader, more amorphous category of imaginary Judaism. It not only confirms the fluid and contradictory nature of the concept, but also tells us that real and imaginary Jews should not be considered opposites. They could converge, even collaborate, in performing the work that imaginary Judaism was set up to do for Christians.

\section{Early Modern Roman Renewal and Conversion}

The long history of Jewish-Christian interaction in Rome was transformed by the religious renewal of the sixteenth-century. The ecclesiastical elite of early modern Rome deliberately sought to remake the city as a model of Christian virtue. After centuries of threats - the Avignon Papacy, the conciliar movement, the Protestant Reformation, and the recent devastating Italian Wars - the Roman Church had emerged largely triumphant. By the 1570s, the Papacy was firmly established in Rome, its coffers were filing, and the protracted Council of Trent had concluded. Energetic religious innovation took many different forms: the growth of confraternities; the founding of very active religious orders; the rise of new forms of public devotion; and expanding overseas missions with local headquarters. Notably, almost all of 
these undertakings welcomed the increasing participation of laypeople in close collaboration with the clergy.

These collective factors lent new weight to all religious actions in the period after the Reformations, perhaps nowhere more than in Rome itself. Late sixteenth-century popes and religious organizations undertook conscious acts of glorifying the city. In so doing, their points of reference were not primarily or explicitly Rome's Jews, or even Judaism itself, but rather its classical past (which they sought to replace); its victories in newly Christianized parts of the world (which they considered a validation of their faith); and its proliferating Protestant antagonists, against whom they sought to build a model of perfect Catholicism. They sought to rebuild Rome as the capital of a newly global religion, a New Jerusalem, a living religious spectacle, a 'hothouse for nurturing all fashionable good works and displaying them to the world. ${ }^{9}$

Renewal efforts took both material and verbal forms. Physical space was intensely contested in Rome as perhaps nowhere else in Europe. ${ }^{9}$ The material process of rebuilding had begun a few decades after the Papacy's return to Rome in 1417. It came to include all the building activity that created Renaissance and Baroque Rome as we picture it: The construction of straight roads, piazze, palazzi, fountains, and churches, including the creation of the via Giulia, Michelangelo's design for the Capitoline Hill, and controversial renovations of St Peter's basilica. ${ }^{10}$ Rhetorical efforts complemented physical ones. Sermons at the papal court embarked on an explicit program of proclaiming the health of the Catholic Church and the particular glory of Rome. Religious processions, devotions, and intensified pilgrimages all contributed to the sanctification of public space. Rome was, as Gregory Martin reminded his

${ }^{8}$ Brian Pullan, 'The Conversion of the Jews: The Style of Italy', Bulletin of the John Rylands University Library of Manchester, lxx (1988), 63. For Catholicism as a world religion see Simon Ditchfield, 'Decentering the Catholic Reformation: Papacy and Peoples in the Early Modern World', Archiv Fur Reformationsgeschichte, ci (2010).

'cf. Laurie Nussdorfer, 'The Politics of Space in Early Modern Rome', Memoirs of the American Academy in Rome, xlii (1999).

${ }^{10} \mathrm{Jean}$ Delumeau, Vie economique et sociale de Rome dans la seconde moitié du XVI siècle, 2 vols. (Paris, 1957); Helge Gamrath, Roma Sancta Renovata (Rome, 1987). 
readers, a 'blessed Citie... a spectacle of fayth \& good workes.' ${ }^{11}$ The papal Holy Year programs of 1575 and 1600, much expanded from previous years, brought pilgrims and tourists from around the world.

These activities, perhaps inevitably, also brought new initiatives intended either to segregate or to integrate outsiders who did not fit the city's pious image - in particular prostitutes, Jews, and paupers, whose numbers all increased in the sixteenth century. Within a year of establishing the ghetto, Pope Paul IV encouraged vagabonds to collect around Piazza del Popolo, away from the city center. In the thirty years after the Council of Trent, 'an everincreasing battery of laws' sought to expel or segregate prostitutes from Roman society. ${ }^{12}$ As Lance Lazar and Brian Pullan have argued, these efforts differed from earlier forms of poor relief by emphasizing moral reform as well as material support. Three Roman houses - for prostitutes, for their daughters, and for catechumens - typify this shift. Founded by Jesuits and run by Jesuit-led confraternities, they sought to rehabilitate (or habilitate) nonconformists into Catholic orthodoxy. None of these groups was new to the city, but their abiding presence became more problematic in a Rome increasingly seeking to model perfect religion.

The Catholic reinvention of Rome had special implications for Jews. Jews had lived in Rome from ancient times, dating their origins there to the second century BC. In Rome, Jews had always been tolerated and protected. They also enjoyed an uncommon level of privilege, partly through the antiquity of their community, and partly thanks to a history of special dispensations for services to the Papacy. Popes from Gregory I to Martin V renewed the bull Sicut Judaeis, which offered legal protection to Jews in Rome and discouraged forcible conversions. The long Middle Ages saw an extended period of relative tolerance, stability,

\footnotetext{
${ }^{11}$ Frederick McGinness, 'Preaching Ideals and Practice in Counter-Reformation Rome', Sixteenth Century Journal, xi (1980); Martin, Roma Sancta (1581), 8. ${ }^{12}$ Lance Gabriel Lazar, Working in the Vineyard of the Lord: Jesuit Confraternities in Early Modern Italy (Toronto, 2005), 12-19.Tessa Storey, Carnal Commerce in Counter-Reformation Rome (Cambridge, 2008), 241, 67-94; Elizabeth S. Cohen, 'Honor and Gender in the Streets of Early Modern Rome', Journal of Interdisciplinary History, xxii (1992); 'Seen and Known: Prostitutes in the Cityscape of Late Sixteenth-Century Rome', Renaissance Studies, xxii (1998).
} 
and civil relations between Jews and others in Rome. ${ }^{13}$ But the sixteenth century witnessed enormous transformation for Rome's Jews, even beyond their sudden population growth. They became pawns in a much more widespread battle for souls. In the Middle Ages, speaking generally, conversion of the Jews was a distant ideal, growing gradually more important through the fifteenth century. But by the late sixteenth century, as religious denominations across Europe increasingly competed for souls, Jewish conversion became a powerful endorsement for any confession. Catholics, in particular, saw Jewish conversion as a special affirmation that could mitigate their many recent trials. In Rome, it became especially urgent. Where Roman Jews had once been protected by their economic usefulness and undeniable romanità, now they seemed like a failure, a threatening tear in the fabric of Catholicism, and an affront to its proud revitalization. ${ }^{14}$ The mid-sixteenth century thus saw the first concerted, practical effort to convert Roman Jews en masse. Supporting or tolerating Judaism no longer sufficed; Jews had to be 'redeemed,' contained, and if possible, converted (to stability, acceptability, Christianity).

Containing Jews in a ghetto was the first step in this broader theological (and sometimes eschatological) plan for Jewish conversion. ${ }^{15}$ The Roman ghetto was established in 1555, gradually but effectively transforming both Jewish and Christian society as it excised Jews from broader Roman life; it was arguably the 'most traumatic redrawing of Rome's urban space during the early modern period.' ${ }^{16}$ The ghetto's Jews were firmly under the eye of the Roman government at the Capitoline Hill. While they did not effect a total segregation,

\footnotetext{
${ }^{13}$ For an overview of the Roman Jewish community, see Attilio Milano, Il Ghetto di Roma: illustrazioni storiche (Rome, 1988), 31-49 and Kenneth R. Stow and Sholomo Simonsohn, eds., The Jews in Rome (Leiden, 1995). ${ }^{14}$ Stow, 'The Papacy and the Jews', 257-258. Lazar, Working in the Vineyard of the Lord, 33.

${ }^{15}$ Kenneth Stow, Theater of Acculturation: The Roman Ghetto in the 16th Century (Seattle and London, 2001), 59-62; Lazar, Working in the Vineyard of the Lord, 105; For Paul IV's eschatology in his Jewish policy, see Stow, Catholic Thought and Papal Jewry Policy 1555-1593 (New York, 1977), 262-277.

${ }^{16}$ Nussdorfer, 'The Politics of Space in Early Modern Rome'; See also Kenneth R. Stow, 'The Consciousness of Closure: Roman Jewry and Its 'Ghet'.' in David B. Ruderman (ed.) Essential Papers on Jewish Culture in Renaissance and Baroque Italy (New York, 1992); For an account of the re-opening of the ghetto which supports this view, see L. Scott Lerner, 'Narrating over the Ghetto of Rome', Jewish Social Studies, New Series viii (2002).
} 
the ghetto's walls suggested physical boundaries for an ever more vigilantly guarded postTridentine orthodoxy. In Rome, a city of spectacle and a conscious example for the rest of the world, visible boundaries mattered. In a similar way, the buildings of the Casa Pia dei Catecumeni e Neofiti later came to dominate the rione Monti, in the southern slopes of the Viminal hill. ${ }^{17}$

Economic inducements also made conversion more attractive. These included both carrots, such as the 1542 Papal bull Cupientes iudaeos allowing Jews to retain their property after converting, as well as sticks, such as the increase in papal taxes on Jews throughout the sixteenth century. As towns throughout Italy increasingly relied on Christian lending houses, or monti di pietà, the usefulness of Jewish bankers waned, and Christians tolerated them less. This was exactly the result sought by the fiery Observant preachers who had traversed the peninsula in the fifteenth century, preaching against Italy's Jews and encouraging the establishment of alternative lending houses. The growth of monti di pietà throughout Italy made it all the more necessary for Jews, as moneylenders, to be constrained and defined within clear borders such as ghettos. ${ }^{18}$ Venice's ghetto was the first, founded in 1516. Rome's monte di pietà was founded during Holy Week of 1539, after a season of Lenten preaching in its favour by Giovanni Maltei da Calvi, commissioner of the Observant Franciscans. Its recent arrival contributed to the escalated anti-Jewish violence surrounding the Good Friday passion plays of that year, and increased tensions between Christians and Jews in Rome. ${ }^{19}$

Theoretical concerns about conversion, strengthened by the Holy See's quest to create a uniform belief system, increasingly found their way into the policies that administered Rome's Jewish community, for example, as justification in the papal bulls that legislated

\footnotetext{
${ }^{17}$ Marina Caffiero, Forced Baptisms: Histories of Jews, Christians, and Converts in Papal Rome (Berkeley, 2012), 10-11.

${ }^{18}$ Brian Pullan, 'Jewish Banks and Monti di Pietà', in Robert C. Davis and Benjamin Ravid (eds.), The Jews of Early Modern Venice, (Baltimore and London, 2001).

${ }^{19}$ Barbara Wisch and Nerida Newbigin, Acting on Faith: The Confraternity of the Gonfalone in Renaissance Rome, (Philadelphia, 2013), 362, 368-70; See also the documents reprinted in Mario Tosi, Il Sacro Monte di pietà di Roma e le sue amministrazioni (Rome, 1937).
} 
taxation. These concerns only increased during and after the Council of Trent, ultimately overshadowing other forms of Jewish-Christian interaction, such as the Christian study of Hebrew. Gianpietro Cafara, head of the Roman Inquisition (and, as Pope Paul IV, founder of the Roman ghetto), decreed the burning of the Talmud in 1553 despite widespread Christian interest in the Talmud, and despite disagreement from some of his closest associates. ${ }^{20}$ Much of the pressure on Jews came, in Kenneth Stow's interpretation, from Paul IV's eschatological fervor, which saw the conversion of the Jews as a necessary precursor to the End of Days. ${ }^{21}$ The bonfires that resulted represent the ascendance of conversionary policy, and the formation of a principle of 'predisposing force' to convert the Jews. ${ }^{22}$

Segregation and conversion, then, might doubly fortify Catholic orthodoxy. Removing Jews into a ghetto served to distill and concentrate the Catholicism of the rest of the city of Rome and give it physical boundaries. Reintroducing Jews into the population as new Catholics further reinforced the city's piety. In an era when laypeople could, at least in theory, choose among Christian confessions for the first time, the battle for hearts and minds was paramount; its chief weapons were instruction, catechism, and supervision. Within JewishChristian policy, conversion became the key priority, and would remain so throughout the modern period. ${ }^{23}$ In particular, Jewish conversion, more than ever, was supposed to be based on persuasion, not coercion, to suit this new, confessional era, a 'century obsessed with defining, teaching, verifying, and enforcing the rectitude of belief and the validity of interior

\footnotetext{
${ }^{20}$ Piet van Boxel, 'Robert Bellarmine Reads Rashi: Rabbinic Bible Commentaries and the Burning of the Talmud', in Joseph Hacker and Adam Shear (eds), The Hebrew Book in Early Modern Italy, (Philadelphia, 2011).

${ }^{21}$ Stow, Catholic Thought and Papal Jewry Policy 1555-1593 Stow, 'The Papacy and the Jews: Catholic Reformation and Beyond'.

${ }^{22}$ Kenneth R. Stow, 'The Burning of the Talmud in 1553, in the Light of Sixteenth-Century Catholic Attitudes toward the Talmud', Bibliothèque d'Humanisme et Renaissance, xxxiv (1972); 'The Papacy and the Jews: Catholic Reformation and Beyond', 261-269; See also Anna Foa, “Limpieza” versus Mission: Church, Religious Orders, and Conversion in the Sixteenth Century.' in Steven J. McMichael and Susan E. Myers (eds.) Friars and Jews in the Middle Ages and Renaissance (Leiden, 2004).

${ }^{23}$ Caffiero, Forced Baptisms, 6.
} 
conversion. ${ }^{24}$ In the early years of these conversionary efforts, Jesuits and other religious orders emphasized persuasive measures based on education and rhetoric.

Within Rome, conversions to Catholicism signaled in microcosm the desired conversion of faraway lands, and the refutation of Protestant successes. The antiquity and the theological importance of the Jews made their conversions a bigger coup than that of a Muslim or Protestant. The conversion of a rabbi, his son, or a family, particularly if wealthy, was especially to be celebrated. ${ }^{25}$ New religious orders gave extra attention to converting Jews: Filippo Neri and Cesare Baronio, leaders of the Oratorian order, took a special interest. The converso background of many early and influential Jesuits fuelled their particular and energetic efforts at conversion. ${ }^{26}$ Both orders also lent institutional support by providing space for conversionary activities.

The act of conversion, as Anna Foa has argued, was fundamentally public, theatricalized and ritualized within the heavy burden Jews already bore as the primary Christian symbol of otherness. ${ }^{27}$ Conversionary preaching to Jews - a sporadic medieval practice revived in the late sixteenth century - was a uniquely socially and theologically charged event. It was perhaps the most important of the public events celebrating Jewish conversion, including the

\footnotetext{
${ }^{24}$ Quotation in Lance Gabriel Lazar, 'Negotiating Conversions: Catechumens and the Family in Early Modern Italy', in Marc Forster and Benjamin J. Kaplan (eds.), Piety and Family in Early Modern Europe: Essays in Honour of Steven Ozment (Aldershot, 2005), 177.

${ }^{25}$ Ibid., 152. Lazar, Working in the Vineyard of the Lord, 116-117; Marina Caffiero, 'I processi di canonizzazione come fonte per la storia dei rapporti tra ebrei e cristiani e delle conversioni’, in Alessandra Bartolomei Romagnoli, Ugo Paoli, and Pierantonio Piatti (eds.) Hagiologica: Studi per Réginald Grégoire ,vol. 1 (Fabriano, 2012); See also the cases of conversion noted in Giovanni Incisa della Rocchetta and Nello Vian (eds.), Il primo processo per San Filippo Neri nel codice Vaticano Latino 3798 e in altri esemplari dell'archivio dell'Oratorio di Roma (Città del Vaticano,1957).

${ }^{26}$ For Oratorians and conversion see Incisa della Rocchetta and Vian, Il Primo Processo per San Filippo Neri II, 268-269, Testimony of Agostino Buoncompagni, 19 Oct. 1600; Satta, 'Predicatori'; For Baronio, see Alberto Bianco, 'Cesare Baronio e la conversione dei Corcos nei documenti d'archivio della Congregazione oratoriana di Roma', in Luigi Gulia (ed.), Baronio e le sue fonti: atti del Convegno internazionale di studi, Sora, 10-13 ottobre 2007, (Sora, 2009); and Peter A. Mazur, 'Searcher of Hearts: Cesare Baronio's History of Conversion', Journal of the History of Ideas, 1xxv (2014); For Jesuits see Robert Aleksander Maryks, The Jesuit Order as a Synagogue of Jews: Jesuits of Jewish Ancestry and Purity-of-Blood Laws in the Early Society of Jesus. (Leiden, 2010).

${ }^{27}$ Anna Foa, 'Il gioco del proselitismo: Politica delle conversioni e controllo della violenza nella Rome del Cinquecento', in Ebrei e cristiani nell'Italia medievale e moderna: conversioni, scambi, contrasti, ed. Michele Luzzati, Michele Olivari, and Alessandra Veronese (Rome: Carucci, 1988), 156.
} 
baptism of catechumens and the execution of recidivists. ${ }^{28}$ Of these, preaching held the greatest potential yield of converts, and was ostensibly the most firmly rooted in persuasion rather than coercion, although the congregation's forced attendance blurs the distinction. As conversionary preaching gained symbolic importance, so too did the theoretical idea of widespread Jewish conversion. Jews and Judaism became so central to Counter-Reformation conversion rhetoric that, as we shall see, Rome's historic Jewish community would be recast as living images of the generic convert.

\section{Sermons to Jews as a public spectacle}

When they began, conversionary sermons joined a series of long-standing Roman spectacles requiring Jewish ritual performance. Two papal bulls of Gregory XIII established and regularized conversionary preaching: Vices Eius Nos in 1577, and Sancta Mater Ecclesia in 1584. The first called for weekly preaching in Rome, but primarily served to establish a college of neophytes to train recent converts as conversionary preachers. Two prominent cardinals oversaw the College: Guglielmo Sirleto, who chaired the Congregation of the Index, and Giulio Antonio Santoro, head of the Roman Inquisition. The Jesuits ran its educational arm. The second bull extended the practice to every location with a Jewish population large enough for a synagogue, and described its desired form and content. By the time of the second bull, weekly preaching was already well established in Rome. ${ }^{29}$

This legislation and other contemporary sources illustrate how conversionary preaching was supposed to proceed. Preaching took place on Saturday afternoons, the Jewish Sabbath;

\footnotetext{
${ }^{28}$ For instances of medieval papal bills permitting or prescribing preaching to Jews, see Stow, Catholic Thought and Papal Jewry Policy, 19-21. Stow notes three such cases, in 1245, 1278, and 1415, none of which took root. Lazar, Working in the Vineyard of the Lord, 115.

${ }^{29}$ Stow, Catholic Thought, 18-20; Lazar, Working in the Vineyard of the Lord, 114-115; Maryks, 175. Piet van Boxel suggests that Santoro's involvement with a committee expurgating rabbinic commentaries may have been linked to the establishment of conversionary sermons. See 'Cardinal Santoro and the Expurgation of Hebrew Literature', in Stephan Wendehorst (ed.), The Roman Inquisition, the Index and the Jews: Contexts, Sources and Perspectives (Leiden and Boston, 2004), and ibid., 'Robert Bellarmine Reads Rashi'. Bullarum, Diplomatum et Privilegiorum Sanctorum Romanorum Pontificum Taurinensis Editio, Seb. Franco, H. Fory et Henrico Dalmazzo (eds.) (Turin, 1857), viii, 188-191; 487-489.
} 
work was prohibited, ensuring Jewish attendance. Sermons lasted about two hours. Preachers were to be theologians, and their sermons were to correspond to the same weekly Torah readings that their audience would have heard earlier that day. Their specific task was to refute rabbinical interpretations of these passages with Christian ones, reminding the Jews of their desolation and error. Although the bull specifies Hebrew preaching, most surviving sermons are in Italian, the standard language for Jewish preaching. ${ }^{30}$

\section{Ritual Roles for Jews}

Rome's Jews were compelled to proceed in a public procession from the ghetto to the sermon's location. This was typically an oratory, rather than a church, so as to protect the sanctity of Christian spaces, though some churches also eventually hosted sermons. ${ }^{31}$ The primary location was the Oratory of the Confraternity of the Most Holy Trinity (Santissima Trinità dei Pellegrini), founded by Filippo Neri in 1549 for welcoming pilgrims to Rome, equipped with a supply of Jesuit preachers, and considered 'one of the largest and most beautiful Oratories in Rome. ${ }^{32}$ Such a location naturally brought Jews, as potential converts to Christianity, further into the public, even international eye. Elsewhere in Italy, Christian 'ghetto-tourists' emphasized Jewish synagogue ritual - hearing and commenting on Jewish sermons in synagogue, and expressing only occasional wishes for conversion. In Rome proselytization was the singular attraction. ${ }^{33}$ Nor were the surrounding Christian crowds always benign. Adriano Prosperi describes the excursion of hundreds of Jews 'from the ghetto

\footnotetext{
${ }^{30}$ Stow, Theater of Acculturation, 9, 36, 69-70; Robert Bonfil, Jewish Life in Renaissance Italy, trans. Anthony Oldcorn (Berkeley, 1994), 239-240; Marc Saperstein, Jewish Preaching 1200-1800: An Anthology (New Haven, 1989), 39-44.

${ }^{31}$ Caffiero, Legami Pericolosi, 271; Satta, 'Predicatori'; Milano, 'Un sottile tormento', 519-520.

${ }^{32}$ See Jean Delumeau, Vie Economique et Sociale de Rome dans la seconde moitié du XVI siecle., 2 vols. (Paris, 1957), 170. Angelico Piladi, Il P. Evangelista Marcellino insigne Predicatore ed Ecclesiaste del secolo XVI (Florence, 1944). Carolyn H. Wood and Peter Iver Kaufman, "Tacito Predicatore: The Annunciation Chapel at the Madonna Dei Monti in Rome," The Catholic Historical Review, xc, (2004), 644 and Christian Hülsen, Le Chiese di Roma nel Medio Evo (Florence, 1927), 209. For Jesuit preachers in the Oratory, see Maryks, 62. Quotation from Camillo Fanucci, Trattato di tutte le opera pie dell'alma città di Roma, (Rome, 1601), 269. ${ }^{33}$ See the travel accounts in Ravid, 'Christian Travelers.' Montaigne's visit to a Jewish circumcision in Rome is the notable exception to this principle.
} 
to the church of the sermon, between throngs of curious people who commented, laughed, insulted, and sometimes passed from speech to action.' Posters on the door of the Oratory and the street outside ordered spectators not to mistreat or accost the Jews on their way to and from the sermon, under threat of fines and whipping. ${ }^{34}$

This ritual procession, and the public conversionary sermons that followed, recalled many other moments when Jews acted in Roman public spectacles. As in many Italian cities, Carnival festivities included special races for animals and notably for Jews, who had to run nude or semi-nude, ridiculed and egged on by the crowds. Uniquely to Rome, Jews also suffered ritualized violence during the period of the Vacant See after the death of a Pope. ${ }^{35}$ When a new Pope was elected, his possesso ceremony contained a staged encounter, developed over centuries, with Rome's Jews, who were also responsible for decorating part of the possesso route at their own expense. At this encounter the Jews presented the Pope with a Sefer Torah, the sacred scroll adorned with rich decoration, as an act of homage. The Pope, in turn, cast it to the ground to represent the supersession of the Old Testament by the New. Each party spoke formulaic phrases: Jews attested to the honor of the gift, and Popes responded that although the Law of Moses was holy and venerable, its Jewish interpretation was vain and condemnable. ${ }^{36}$ In 1581 , a Roman forty-year-old would have had five opportunities since infancy to watch this ritual encounter during the possesso.

Thus by the time conversionary sermons were established, 'Imaginary Jews' were a well-established visual category: Christians and Jews alike in Rome were accustomed to seeing individual Jews publicly perform the abstract role of 'The Jews' in various ritualized

\footnotetext{
${ }^{34}$ Adriano Prosperi, 'L'inquisizione Romana e gli ebrei', in Michele Luzzati (ed.), L'Inquisizione e gli ebrei in Italia (Bari, 1994), 105-106; Milano, 'Un sottile tormento', 524.

${ }^{35}$ Martine Boiteux, 'Les Juifs dans le carnaval de la Rome moderne, XVIe-XVIIIe siècles', Mélanges de l'Ecole française de Rome. Moyen-Age, Temps modernes, lxxxviii (1976). John M. Hunt, 'Violence and Disorder in the Sede Vacante of Early Modern Rome, 1559-1655' (The Ohio State University, 2009), 259-73.

${ }^{36}$ Adriano Prosperi, 'Incontri rituali: il papa e gli ebrei', in Corrado Vivanti (ed.), Gli ebrei in Italia, (Storia d'Italia: annali XI , Turin, 1996), 502-503; Amnon Lindner, “"The Jews Too Were Not Absent...carrying Moses's Law on Their Shoulders": The Ritual Encounter of Pope and Jews from the Middle Ages to Modern Times', Jewish Quarterly Review, xcix (2009).
} 
contexts. Of these, conversionary sermons were arguably the most acutely symbolic. Sermons focused on the very moment of choosing and validating Catholicism, thus helping to define the borders of Catholic identity. Unlike in the possesso ceremony, the visual role of Jews in conversionary sermons was not primarily to demonstrate inferiority. Instead, the silent, listening Jews modelled the possibility of universal penitence, recalling the injunction of 1 Corinthians 12:13: 'For in one Spirit were we all baptized into one body, whether Jews or Gentiles, whether bond or free; and in one Spirit we have all been made to drink. ${ }^{37}$ As one contemporary preacher put it, 'Do you see how many Jews have converted in the past few years?... Jews, do not linger any longer, if you want to heal from your infirmities. Christians, come to the pool of penitence, do you not see that the waters have been disturbed? ${ }^{38}$ For him, the sight of Jewish conversion also signified Christian contrition.

\section{Conversionary Preaching Networks}

Our three primary memoirists - the anonymous diarist, Montaigne, and Martin expand our picture of the weekly spectacle. Together they confirm the location and the compulsory attendance, the reliance on specialized knowledge of Jewish texts, and the identity of many preachers and their supporters. The diarist first noted, on 6 May 1587, 'I went to the Oratory of the Trinity to the sermon to the Jews of P. Marcellino and M. Andrea.' He returned three more times that summer. ${ }^{39}$ These dates represent a tiny proportion of his sermon visits over nearly two decades. But by the same token, they indicate both the high profile of the 'predica alli Giudei' alongside other public sermons, and the peak moment of Catholic interest in Jewish conversion in the early

\footnotetext{
${ }^{37}$ Douay-Rheims translation.

38 'Vedete quanti Giudei si sono convertiti pochi anni sono...Venite non indugiate più, se volete guarir di tante infermità vostre. Christani, venite alla Piscina dela penitentia, non vedete conturbate l'acque?' Delle Prediche Quadragesimali del R.mo Mons.or Cornelio Musso, Vescovo di Bitonto, Sopra l'Epistole \& Eangeli correnti per i giorni di Quarisma Vol. I (Venice, 1587), 285.

${ }^{39}$ ASV Fondo Borghese IV, 145. Quotation on fol. 75r. Dates on fols. 75r-77v: 27 May, 3 June, 8 July.
} 
1580s. Montaigne was impressed when he too attended during Lent of the same year, singling out:

That renegade rabbi who preaches to the Jews on Saturday after dinner in the Church of the Trinity. There are always sixty Jews there; this number is compelled to attend. He was a very famous doctor among them, and by their very arguments, by their rabbis, and by the text of the Bible, he combats their belief. In that science and in the languages used in it he is admirable. ${ }^{40}$

Gregory Martin's Roma Sancta helpfully provides the names of many preachers. Although Martin took great pains to present Rome as a city of unwavering piety - an agenda that sometimes whitewashed his depictions - his account, however exaggerated, nonetheless confirms many verifiable details:

There come up into the pulpit two excellent men...the one and the first, a Jesuite or some other of greate skil and good spirit, to move: The other, a great Rabbine sometime of their owne, but now these manie yeare a zelous and learned Christian, named maister Andreas.... his knowledge of readinesse in the Hebrew Bible and al the Hebrewe commentaries and Chaldee Paraphrases and the Syriake and Arabike tong... well, this man is chosen of purpose to confute them out of their owne bookes and doctors, to confound them $[\ldots]$ and especially the zele and compassion that they declare toward the saving of their soules doeth much move and persuade, God principally working withal in their hartes. Father Possivino the Jesuite

\footnotetext{
${ }^{40}$ Montaigne, 956-957.
} 
occupied the place...after him Lupus a Capuchine, and after him Francisco

Maria, al famous men and ful of Zele and charitie. ${ }^{41}$

These men formed part of a close network of clerical patrons and powerful religious orders. ${ }^{42}$ Antonio Possevino, the well-known Jesuit secretary, theologian, and diplomat, was closely involved in founding the College of Neophytes, and preached at the Oratory of the Trinity for six months in 1577 . He also defended converso Jesuits in debates about their status within the Jesuit order. ${ }^{43}$ Martin's 'Lupus' is Alfonso Lupo, a Spaniard who had preached in Rome against the laws of limpieza de sangre, which prevented Muslim and Jewish converts and their descendants from ordination as priests and from holding many other offices. Lupo was a close associate of Neri and the Oratorians. Contemporary sources are full of praise for his preaching, indicated by the popular maxim, 'Hebraeus docet, Lupus movet, Panigarola delectat. ${ }^{44}$ Martin elsewhere calls Lupo 'a very spiritual and zealous man.' ${ }^{45}$ The anonymous diarist attended at least eighteen of Lupo's sermons throughout Rome; three times, immediately after attending a conversionary sermon. 'Francisco Maria' is probably Francisco Maria Tarugi, future cardinal and archbishop, Oratorian, and Lupo's close associate. ${ }^{46}$

\footnotetext{
41 Martin, 78-82.

${ }^{42}$ Piet van Boxel has also taken up the task of highlighting this passage and identifying the figures mentioned in it. Jewish Books in Christian Hands: Theology, Exegesis and Conversion under Gregory XIII (15721585) (Città del Vaticano, 2016), 14-18. His book, which examines censorship and scriptural exegesis as they relate to conversionary preaching, only appeared after this article was completed.

${ }^{43}$ For Possevino's background see John Patrick Donnelly, 'Antonio Possevino and Jesuits of Jewish Ancestry', Archivum Historicum Societatis Iesu, lv (1986); Maryks, The Jesuit Order, 62; Emanuele Colombo, 'The Watershed of Conversion: Antonio Possevino, New Christians, and Jews', in James William Bernauer and Robert A. Maryks (eds.), 'The Tragic Couple': Encounters between Jews and Jesuits, (Leiden, 2014), $25-42$. ${ }^{44}$ For Lupo, see Miguel Gotor, I Beati del Papa: Santità, inquisizione e obbedienza in età moderna (Firenze, 2002), 92-96, 122; Romeo De Maio, Riforme e miti nella chiesa del cinquecento (3 ${ }^{\text {rd }}$. ed., Naples, 1992), 145; 347; Fedele Merelli, 'P. Alfonso Lupo cappuccino e san Carlo Borromeo', L'Italia Francescana lxiv (1989). Dermot Fenlon, 'Pole, Carranza, and the Pulpit', in John Edwards and Ronald Truman (eds.), Reforming Catholicism in the England of Mary Tudor: The Achievement of Friar Bartolomé Carranza (Aldershot, 2005), 96-97; Extensive copies of Lupo's sermons to Neri's circle survive in manuscript at the Biblioteca Vallicelliana. The other two preachers in the maxim are Alessandro Franceschi (1543-1601) and Francesco Panigarola (15481594).

${ }^{45}$ Martin, 82.

${ }^{46}$ Dizionario Biografico degli Italiani (DBI), s.v. Filippo Neri.
} 
Conversionary preachers such as these were all rising stars in Rome's clerical elite, or their close friends.

The lynchpin in this story, and the only person mentioned by all three sources, is Martin's 'Maister Andreas,' the convert Andrea De Monte. Born in Fez, Rabbi Joseph Moro was baptized by Pope Julius III Del Monte in 1552, and given his surname. His appointment as the first fixed preacher to the Jews, held in exchange for house and livelihood, began in 1576. De Monte was largely responsible for the institutionalization of conversionary preaching under Gregory XIII, and was also charged with censoring Jewish books in Rome and Spoleto. De Monte, a vehement preacher, was unpopular - constrained first to preach with an associate, and soon after, to give up the pulpit in 1582 because of audience resentment. After that time, he remained close to subsequent Popes and to Filippo Neri, and worked nonetheless to regulate their conversionary practices towards Jews. ${ }^{47}$ De Monte is by far the best known conversionary preacher and Jewish convert in early modern Rome.

Yet the figure who best represents conversionary preaching, both as spectacle and as rhetoric, is not De Monte, but the 'P. Marcellino' listed next to him in the diary. This is Evangelista Marcellino, an Observant Franciscan. Marcellino, known al secolare as Lorenzo Selva or Gerbi, was a prolific and popular preacher throughout Rome. Starting in the 1580s, Marcellino served as the specially appointed explicator of scripture at the Observant church of Santa Maria in Aracoeli. ${ }^{48}$ His printed output included sermons, theological treatises, a popular

\footnotetext{
${ }^{47}$ For De Monte see Fausto Parente, 'Notes biographiques sur André de Monte', in Les Juifs et l'Église Romaine à l'époque Moderne (XVe-XVIIIe Siècle), (Bibliothèque d'études Juives 29, Paris, 2007), and the entry by the same author in the DBI, s.v., as well as De Maio, Riforme e miti nella Chiesa del Cinquecento, 349-350; Wood and Kaufman, 'Tacito Predicatore'; Gian Ludovico Masetti Zannini, 'La biblioteca di Andrea Del Monte (losef Sarfath) e altre librerie di ebrei nel cinquecento Romano', in Giorgio De Gregori and Maria Valenti (eds.) Studi di biblioteconomia e storia del libro in onore di Francesco Barberi (Rome, 1976); Boiteux, 'Preaching to the Jews in Early Modern Rome: Words and Images', 301-305; the anonymous letter reporting Jewish complaints against De Monte is reprinted in Fausto Parente, 'Il Confronto Ideologico tra l'ebraismo e la Chiesa in Italia', in Italia Judaica. Atti Del I Convengo Internazionale, Bari, 18-22 Maggio 1981 (Rome, 1983), 378-379.

${ }^{48}$ Early bibliographical sources include Delle Historie del Mondo descritte dal Sig. Cesare Campana (Venice, 1597), 570; the vita by Jacopo Peri in Prediche della Passione e Resurrezione di Giesu Criso nostro Redentore. Fatte l'anno 1592 in Roma dal R.P.F. Vangelista Marcellino (Florence, 1622); Federico Borromeo, De sacris nostrorum temporum oratoribus libri quinque (Milan, 1632); Giuseppe Dondori, Della pietà di Pistoia (Pistoia, 1666), pp 302-312. Modern sources include Gustavo Cantini, I Francescani d'Italia di fronte alle dottrine
} 
prose romance, and many books of Old Testament exegesis based on his sermons. Marcellino was also clearly the associate hired to accompany Andrea De Monte. Where Martin notes another preacher in the pulpit with De Monte, and the diarist hears 'P. Marcellino and M. Andreas' together, Marcellino himself confirms their association: 'My dearest Mr Andrea Monte, with whom I have been joined against the Jews for ten years now. ${ }^{49}$

\section{Christians at Conversionary Sermons}

The diarist, Martin, and Montaigne all confirm that the Christian presence at these sermons was customary, expected, and necessary. Gregory Martin describes the sermon spectacle, with catechumens and neophytes, dressed in white and black respectively, seated among an illustrious, varied crowd of Christian onlookers:

The cheefe of the Christians in this Audience is always a Cardinal, as it were by office deputed to be president of this exercise, as for other causes, so especially to keepe the Jewes in awe, and to rebuke them for absence or slacknesse, ... with him commonly are other cardinals, sometimes eight at once, after them bishopes, referendaries, prelates of al degrees, doctors of divinitie and of the Rota, noble citizens and straungers, briefly of al countries and states, flocking hither so thinke as to no other exercise byseides, that to sitte thou must come betimes, yea if you come late there is no place for thee to stand within the doore. ${ }^{50}$

luterane e calviniste durante il cinquecento (Rome,1948). The fullest information is found in Angelico Piladi, Il P. Evangelista Marcellino. See also Gotor, I beati del papa, 79-85; Emily Michelson, 'Evangelista Marcellino: One preacher, two audiences'; ibid., 'Dramatics in (and out of) the pulpit in post-Tridentine Italy', The Italianist xxxiv (2014).

49 'mi dice il mio Carissimo Messer Andrea Monte, col quale già per dieci anni sono congiunto contra gli Ebrei,' Lezzioni Diciannove sopra Rut. Del RPF Vangelista Marcellino de’ Minori Osservanti. (Florence, 1586). 34r. See also Michelson, "Evangelista Marcellino: One preacher, two audiences."

${ }^{50}$ Martin, 77. 
The printed record corroborates Martin's account. Evangelista Marcellino's volume of printed sermons, Sermoni Quindici, directly confirms a Christian audience in various ways. It is dedicated to Guglielmo Sirleto, Cardinal of Santa Severina, who habitually attended the sermons in his role as cardinal-protector of the College of Neophytes. Marcellino acknowledges Sirleto's regular attendance over seven years and rhetorically excuses the cardinal from reading sermons he has already heard aloud. He also indicates the presence of many other prominent clerics, mentioning by name Gabriele Paleotti, newly-confirmed archbishop of Bologna and close correspondent of Sirleto. The sermons' broader publicity, Marcellino explains, has led him to publish them in the vernacular version that so many people have already heard. Marginal notes in the book instruct an intended audience of Christian readers. These explain the different enumeration of Biblical books ('note that the text is cited here as it is in Hebrew') and carefully define various sacred texts in the sermons. Jewish listeners may or may not have known that Midrash Tehillim is a gloss on the book of psalms, but most Christian listeners and readers surely did not. ${ }^{51}$

Marcellino's volume appears to be the only full volume of Roman sermons to Jews published in the sixteenth century, making it, by some standards, the most surviving important example of conversionary sermons. It appeared in 1583, just after Marcellino's associate De Monte gave up preaching, and it captures the initial years of established weekly conversionary preaching. It represents the public face of this new practice within its network of Christian supporters, and sets the standard for an emerging genre of texts: the published polemic by a conversionary preacher. ${ }^{52}$

\footnotetext{
${ }^{51}$ Marcellino, Sermoni quindici sopra il salmo centonoue fatti a gli hebrei di Roma dal r.p.f. Euangelista Marcellino dell'Ordine de' minori osseruanti (Florence, 1583), 'Dedica' at unpaginated fols. a2r-a4r. Milano, Il ghetto di Roma, 284; Lazar, Working in the Vineyard of the Lord, 114; Alberto Zucchi, 'I Predicatori Domenicani degli Ebrei in Roma', Memorie Domenicane, li: 5 (1934): 313-22. Wood and Kaufman, 'Tacito Predicatore', 636 and passim. 'Nota che si cita il testo come sta nell'Hebreo' Sermoni Quindici, 18, 3.

${ }_{52}$ Many disputations and treatises by preachers refuting Jewish theology were printed in the $16^{\text {th }}-18^{\text {th }}$ centuries, often by conversionary preachers, e.g. Giuseppe Ciantes, Della Santissima Trinità, evidentemente provata da $i$ testimoni de gli antichi Ebrei (Rome, 1668).
} 
Marcellino's practice of addressing Christians in print held for other printed conversionary sermons and polemical literature. Like Marcellino, later authors used Christian printers (sometimes collaborating with Jewish authors), usually wrote in the vernacular, and employed paratexts - particularly dedications - that assumed a Christian readership and a network of Christian patrons. ${ }^{53}$ Thus although conversionary sermons appeared to address Jews, Jews were never considered the sole audience, orally or in print. From the first, sermons drew Christian observers, and addressed Christians as much as Jews. Conversionary preachers would thus always have had their double audience in mind, and sometimes even acknowledged them aloud. To his Jewish audience, Marcellino said, 'I do not doubt that this sermon of mine, for all that it is high and profound, will nonetheless be understood by my faithful, who will have taken it with that meaning and sweetness, that you have not taken.' 54

The heavy emphasis on Christian audiences suggests that they were essential to the entire enterprise. Although fixed weekly conversionary preaching was new, its Christian spectators would easily have grasped that their role, too, was ritually indispensable. As Edward Muir has shown, ritual actors and viewers were mutually dependent, with one emanating certain values and the other confirming their efficacy and emanating values of their own. ${ }^{55}$ Christian spectators could absorb the penitential performance of the Jewish audience, while modelling the righteousness that the sermons were supposed to effect, or indeed, undertaking their own penance in response. By the early seventeenth century, Paul V had granted a 50-year indulgence to confraternity brothers of Santissima Trinità dei Pellegrini

\footnotetext{
${ }^{53}$ For Hebrew books in Christian printing houses, see Amnon Raz-Krakotzkin, The Censor, the Editor, and the Text: The Catholic Church and the Shaping of the Jewish Canon in the Sixteenth Century (Philadelphia, 2007); For formatting in Hebrew books, see David Stern, 'The Rabbinic Bible in Its Sixteenth-Century Context', in Hacker and Shear (eds.), The Hebrew Book in Early Modern Italy.

54 'Onde io non dubito punto, che questo mio sermone, con tutto che sia stato alquanto alto \& profondo, nondimeno appieno sarà stato inteso da i miei fideli, con l'haverne preso, quel gusto, \& quella dolcezza, che voi non haverete presa.' Sermoni quindici, 107.

${ }^{55}$ Edward Muir, 'The Eye of the Procession: Ritual Ways of Seeing in the Renaissance', in Ceremonial Culture in Pre-Modern Europe, ed. Nicholas Howe (Notre Dame, IN, 2007), 144.
} 
who attended conversionary sermons in their Oratory. ${ }^{56}$ The indulgences for this confraternity also approve a range of other pious activities, such as the Seven Churches of Rome pilgrimage, the Forty-Hour Devotion, and the ritual foot-washing of pilgrims. Many sermon onlookers would have been members of similar confraternities, participating in weekly or yearly public devotions. Others, like the diarist, attended public sermons during Lent, sought out sacre rappresentazioni, public baptisms, or penitential processions. Many of these devotions were revived, established, or heavily promoted by the Congregation of the Oratory and its confraternity. Like conversionary preaching, Holy Year rituals often took place inside the Oratory itself. This shared institutional patronage reminds us that conversionary sermons must be considered not only alongside other conversionary efforts, but equally as part of a range of similarly new and public rituals for Catholics proclaiming the piety of Rome and its citizens. The devout public witness was a familiar role easily adapted to the conversionary sermon.

The arrangement of the conversionary spectacle, with its ritual procession, its tiers of participants, and its public nature, made it a highly symbolic act for all involved. By attending conversionary sermons, Jews, Christian onlookers, and neophytes were all enacting universal roles. Roman Jews, ostensibly the target audience, modeled and inspired the prospect of Christian penitence. Neophytes confirmed that it was indeed possible. The Christian onlooker was the pious spectator ready to convert his own heart in imitation of these models. In this way, the universal category of 'imaginary Jew' enacted at conversionary sermons was visual as well as aural, and included neophytes and Christians in its embrace.

\section{Jews in Roman sermon rhetoric.}

\footnotetext{
${ }^{56}$ Sommario delle gratie, indulgenze, e privileggi concessi dalla Fe. Mem. di Papa Paolo V all Ven. Archiconfraternita della Santissima Trinità de' Convalescenti e Pellegrini di Roma (Rome, 1674). Archivio di Stato di Roma (ASR), fondo Trinità dei Pellegrini, 523.
} 
Awareness of this layered audience permeated conversionary rhetoric. It surfaced in a preacher's occasional asides, but also wound deep into the structure of sermons themselves, and especially into the word at their heart, 'Jew' - a word uttered in different rhetorical contexts throughout Rome. Roman Jews at conversionary sermons heard themselves addressed with a label - 'O Jews' - that could apply directly to them in their particular historical context, but that could equally carry an abstract meaning where Jews were absent. Christians who walked into the Oratory on Saturday afternoons brought with them the preconceptions and theological concepts about Jews they had heard from other pulpits.

Although Catholic and conversionary sermons derived from different textual traditions, both kinds of sermons used the word 'Jew' in similar ways. Both avoided specific references to the Roman Jewish community. Instead, the word 'Jew' took on a broad, more generic meaning that never referred exclusively to the living Jewish audience. It is important to note that in both genres, preachers could have employed other rhetorical options instead of this more abstract usage. In other words, Jews were always invoked in the same manner in Roman sermons whether or not they were actually present. Even in the special context of conversionary sermons, the word 'Jew' bore only a general meaning that could apply equally to an audience of Christians and of Jews.

\section{Jews in Marcellino's conversionary sermons}

Conversionary sermons are a particular sub-genre of preaching, derived from an interrelated group of medieval sources, primarily Jewish-Christian disputations and the growing body of polemical conversionary or anti-Jewish treatises. These sources shared a rhetorical strategy. Their goal was to prove that canonical Jewish texts - Scripture, Talmud, and Kabbalah - in fact validated Christian doctrines regarding the Messiah. Priests and polemicists grappled closely with these texts, working their way through a series of exegetical proofs. They argued that if read correctly, the Hebrew Bible would reveal that the Messiah 
had already come, that the Messiah was in fact Jesus Christ, and that he was born of a virgin.

As a corollary, they often insisted that the rabbinic authors of post-biblical texts had knowingly and misleadingly concealed this information from their faithful. ${ }^{57}$

Medieval disputations and polemics thus set a precedent of exegetical close readings, grammatical analyses, and detailed discussions of doctrine in biblical and rabbinic texts. ${ }^{58}$ These techniques passed directly into the conversionary sermons that often resulted, as with the preaching campaign of Paul Christiani after the Barcelona disputation of 1263. The later injunctions of Vices Eius Nos and Sancta Mater Ecclesia added further constraints: Sermons should emphasize the advent and incarnation of Christ, his birth, life, miracles, passion, death, burial, descent into hell, resurrection, ascension, and the later confirmation of his gospel through the miracles and the preaching of saints and apostles. They should point out the desolation and dispersion of the Jews, the frustration of their vain hopes, and the duplicity of their rabbis in promoting false interpretations of scripture.

Marcellino's sermons preserve the exegetical approach of medieval polemicists. His fifteen sermons provide an extended analysis of one psalm, 109 in Christian numbering. Marcellino reads the psalm closely, dissecting its grammar and its various rabbinical interpretations. Using his expertise in Jewish sources, he argues that this psalm, like all Jewish texts, actually demonstrates Christian truths: Christ as Messiah and Redeemer, the Trinity, the virginity of Mary, the necessary misery of Jews. ${ }^{59}$ As a result, Marcellino refers to Jews primarily in general terms. He might address his listeners directly, if vaguely, as 'O Giudei' or

\footnotetext{
${ }^{57}$ For the evolution of this idea in particular, see Parente, 'Il confronto ideologico tra l'ebraismo e la Chiesa in Italia'.

${ }^{58}$ For some of the vast literature on medieval disputations, see Robert Chazan, Barcelona and beyond: The Disputation of 1263 and Its Aftermath (Berkeley, 1992); ibid., Fashioning Jewish Identity in Medieval Western Christendom (Cambridge, 2004); Harvey J. Hames, The Art of Conversion: Christianity and Kabbalah in the Thirteenth Century, (The Medieval Mediterranean xvi, Leiden, 2000); Robin J. E. Vose, Dominicans, Muslims and Jews in the Medieval Crown of Aragon (Cambridge Studies in Medieval Life and Thought, fourth ser., lxxiv Cambridge, 2009); David Berger, Persecution, Polemic, and Dialogue: Essays in Jewish-Christian Relations, (Boston, MA, 2010); Paola Tartakoff, Between Christian and Jew: Conversion and inquisition in the crown of Aragon, 1250-1391 (Philadelphia, 2012).

${ }^{59}$ See Michelson, 'Evangelista Marcellino: One preacher, two audiences'.
} 
even 'carissimi Hebrei,' but his sermons do not mention the particular circumstances of Roman Jews as cohabitants of the same city as himself, nor the constellation of conversionary efforts aimed at them. Even though he often evokes 'the modern rabbis,' the Jews he describes are trans-historical, their sins eternal and their character unchanging, eternally subject to the labels used by scriptural prophets: 'O Jews, for how long will you display that mendacious style, for which God reprimands you so often through Jeremiah, Chapter Eight? For how long will you be so heavy-hearted that nothing delights you except vanity and lies, as David says in Psalm Four?'60

This general call to convert is timeless. Marcellino's only concession to chronology is to acknowledge a post-biblical history in which Jews should no longer observe commandments:

You, on the contrary, until [Christ's] coming observed [the law] very little, and after he came, you want to observe and to observe so much that, as much as possible, you do not transgress one iota [...] and now see that for fifteen hundred and eighty-two years nothing has come to you except the contrary of what you wish for. ${ }^{61}$

Marcellino's conversionary preaching thus considers Jews primarily as a static category. His approach to persuasion does not extend to acknowledging their personal circumstances. Even a reference to the Passover feast - a high point in the Jewish year and one still undergoing ritual innovation in the early modern period - is treated only as an event in the past: 'Just as your fathers celebrated Pasqua one time when they left Egypt, but then every year made a

\footnotetext{
60 'ò Hebrei in fino à quanto si troverrà in voi quello stile mendace, onde tanto \& tanto per Gieremia Cap. 8 vi riprende Iddio? In fino à quanto sarete cos gravi di cuore che d'altro non vi dilettiate che di vanità $\&$ di bugia secondo che al 4. Salmo dice David?' Sermoni Quindici, 22.

61 'voi per contrario, infino al suo avvento poco l'havete osservata anzi non punto \& dopo che venuto è, la volete osservare $\&$ tanto osservare che per quanto si può non se ne preterisca un iota $[. .]$.$\& ben vedete che per mille$ cinquecento \& ottanta dua anni non vi è avvenuto se non il contrario di quanto volete.' Sermoni quindici, 49-50.
} 
memorial to it, so do we make a daily and continual memorial to that which Christ did once. [italics added] ${ }^{62}$ Mentioning a current practice might have helped Marcellino's argument; he could not have been ignorant of the Jewish liturgical calendar, which determined his Saturday preaching.

Marcellino's close adherence to medieval precedent suggests a lost opportunity. These fifteen sermons capture a unique moment: the first establishment of frequent and regular conversionary preaching to an historic, well-defined community. Yet neither Marcellino nor subsequent conversionary preachers did much to develop new preaching styles, or to address the particular circumstances of the listeners. They almost invariably took the same approach as Marcellino, with the same arguments. The manuscript record - uneven for the sixteenth century but stronger for the seventeenth - confirms that a strictly general treatment of Jews was the norm in conversionary sermons, for which print and manuscript versions are very similar. ${ }^{63}$ The very invariability of conversionary sermons as an established genre suggests that they were not, as a whole, concerned to accommodate the particular circumstances of sixteenth-century Roman Jews, or closely connected to other contemporaneous conversionary efforts.

\section{Jews in other Roman sermons.}

We can also expect conversionary sermons to share characteristics with other contemporary Christian sermons, particularly those preached elsewhere in Rome during Lent and festivals. The concept of persuasion was a primary concern in all early modern sermon

\footnotetext{
62 'Si come appo i vostri padre, una sola volta si celebrò la fase cioè Pasqua quando uscirno di Egitto, ma poi ogn'anno ne facevano memoria. Cosi noi facciamo diurna \& continua memoria di quella che una sol volta fece Christo.' Sermoni quindici, 125. For Passover liturgical innovations in Renaissance Italy, see Bonfil, Jewish life in Renaissance Italy, 223.

${ }^{63}$ Based on a survey of 16 th and 17 th-century conversionary sermons in manuscript preserved at the BAV. One exception is an early conversionary sermon published by Ludovico Carretto, which has little precedent or imitation. Epistola de Ludovico Carretto ad Hebreos. Sermon di Giulio Innocentio suo figliolo alli Hebrei (Genoa, 1556). See Robert Bonfil, 'An Infant's Missionary Sermon Addressed to the Jews of Rome in 1553.' In Elisheva Carlebach and Jacob J. Schacter (eds.) New Perspectives on Jewish-Christian Relations: In Honor of David Berger (Leiden, 2012) and 'Chi era Ludovico Carretto, apostata?', in Guido Nathan Zazzu (ed.) E andammo dove il vento ci spinse. La cacciata degli ebrei dalla Spagna (Genoa, 1992).
} 
rhetoric. ${ }^{64}$ Jews were an especially potent symbol in Rome's grandest pulpits, often invoked in prominent sermons. Yet the intended audience in this case was not the Jews, but the body of the Catholic faithful.

The preacher who best embodied preaching tropes in Rome was the Conventual Franciscan Cornelio Musso, house preacher to Cardinal Alessandro Farnese and the Farnese family of Popes and patrons. ${ }^{65}$ Musso was an apt model for Marcellino and other acclaimed preachers. His pulpit, the Farnese church of San Lorenzo in Damaso, was the most prominent stop on the city’s sermon circuit after St Peter's. Gregory Martin's Roma Sancta lists San Lorenzo in Damaso second only after St Peter's in its discussion of preaching. The diary author heard Alfonso Lupo preach there and in some years visited the church almost daily during Lent. The Lenten sermons that Musso preached in San Lorenzo in Damaso in 1539 and 1540 were polished over the course of his later career and published in a complete set in the late 1570s, just as Marcellino was first printing his own religious works.

References to Jews saturate Musso's sermons; Jews merit more attention than any other antagonist, whether Protestants, Ottomans, or Satan himself. Musso uses them in three ways, reviewed very briefly here. First, Jews are invoked often as part of the Lenten, specifically Franciscan, rhetoric of Jewish ingratitude, deicide, and stubbornness: 'Jews, why have you violated the law against this friend? You have hated, injured, surrounded, infiltrated, oppressed, tormented, and killed him. ${ }^{66}$ Second, and more frequently, they served as a mirror to Christian behavior: 'Do you see that even the Jews have the Bible read on Saturday in their

\footnotetext{
${ }^{64}$ John O'Malley, Praise and Blame in Renaissance Rome: Rhetoric, Doctrine, and Reform in the Sacred Orators of the Papal Court, C. 1450-1521 (Durham, NC, 1979); Frederick McGinness, Right Thinking and Sacred Oratory in Counter-Reformation Rome (Princeton, 1995); Marc Fumaroli, L 'Age de l'éloquence: rhétorique et 'res literaria' de la Renaissance au seuil de l'époque classique (Geneva, 1980).

${ }^{65}$ Gustavo Cantini, 'Cornelio Musso dei frati minori conventuali (1511 - 1574), predicatore, scrittore, e teologo al Concilio di Trento’, Miscellanea Francescana, xli (1941); Corrie Norman, Humanist Taste and Franciscan Values: Cornelio Musso and Catholic Preaching in Sixteenth-Century Italy. (New York, 1998); Emily Michelson, The Pulpit and the Press in Reformation Italy (Cambridge, MA, 2013); Hubert Jedin, 'Der Franziskaner Cornelio Musso, Bischof von Bitonto: sein Lebensgang und seine kirchliche Wirksamkeit', Römische Quartalschrift xli (1933): 208-75.

66 'Giudei. Perche havete violato tutta la sua legge contra di questo amico? L'havete odiato, perseguitato, afflitto, calonniato, ingiuriato, circonvenuto, insidiato, oppresso, tormentato, ucciso.' Delle Prediche Quadragesimali del R.mo Mons.or Cornelio Musso, Vescovo di Bitonto (Venice, 1587). Vol II, 434.
} 
synagogues... what shame is ours, that the gospel of Christ is not read or preached every festival... Go to masses... go to the churches, which are the houses of God! ${ }^{67}$ Finally, and most frequently, Musso called for their conversion: 'O cruel and impious dogs, who could ever say how many times you oppressed Christ, Synagogue?... How much better would it be for you if you converted to Christ. He is still ready to pardon you, and to put you back in his grace.' ${ }^{98}$ 'O Jews, at the example of the Ninevites do penance at the preaching of the resuscitated Jonah, the triumphant Christ, if you do not wish to perish. ${ }^{69}$

In these sermons, Musso reserves exhortation only for Romans and for Jews: 'O Roma!' 'O Giudei!' He addresses no other group directly. But unlike his Roman listeners, who really heard him, Musso's Jews did not. It was a rare exception when Jews were permitted, or snuck into, a prominent church such as San Lorenzo in Damaso. ${ }^{70}$ When he uttered the words ' $O$ Giudei,' as he did frequently, he applied them to Christian listeners.

Musso's persistent lack of specificity about Jews suggests a deliberate choice. In many ways, his rhetoric, like Marcellino’s, maintained medieval conventions; Jews as Christ-killers, counter-examples, and converts are traditional themes in Lenten Franciscan preaching. Nonetheless Musso's rhetoric departs from the precedent of his own order. The fifteenthcentury Observant preachers who enraptured northern Italy often framed their harsh antiJewish sentiments in practical and social terms, condemning Jewish-Christian socializing and

\footnotetext{
${ }_{67}$ 'Vedete che infino i Giudei fanno leggere la Bibia il di del Sabbato nelle loro Sinagoghe.. Che vergogna è la nostra, che non si legga ò predichi ogni festa l'Evangelio di Christo? ... Andate alle messe... Andate alle Chiese, che sono case di Dio.' Prediche sopra il Simbolo de gli Apostoli ... Del R.mo Mons.or Cornelio Musso Vescovo di Bitonto. Predicate in Roma la Quaresima l'Anno MDXLII nella Chiesa di S. Lorenzo in Damazo, (Rome, 1601), 436.

68 'O cani crudeli, \& empii... chi potrebbe mai dire quante volte opprimesti Christo, Sinagoga? ... Deh quanto vi sarà meglio Giudei, à convertirvi à Christo. E ancora pronto à perdonarvi, à rimettervi in gratia sua.' Prediche Quadragesimali II, 428-429.

69 'O Giudei, all'essempio di Niniviti fate penitentia alle predicationi del risuscitato Giona, del trionfante Christo, se non volete perire.' Prediche Quadragesimali, II, 386.

${ }^{70}$ For one such example, see Stephen Bowd, 'The Conversion of Margarita: A Wedding Oration in FifteenthCentury Brescia', Archivio Italiano per la storia della pietà xxv (2012): 152-153; For Jews in churches in Early Modern Rome, see Gerd Blum, 'Vasari on the Jews: Christian Canon, Conversion, and the Moses of Michelangelo', The Art Bulletin xcvi (2013). Musso's church of San Lorenzo in Damaso hosted occasional conversionary sermons.
} 
encouraging Jewish expulsion. ${ }^{71}$ Unlike these mendicants, Musso in Rome could hardly have advocated for specific legislation regarding Jews. The Holy See set policy, and it preferred conversion to expulsion. But where he might, like Bernardino of Siena, have denounced interactions between his listeners and their Jewish neighbors, he did not. Musso's sermons contain only the broadest, most general evocations of Jews. ${ }^{72}$

Moreover, in Musso's Rome, living Jews were increasingly prominent in a Rome where imaginary Jews had always already mattered. Rome's preachers surely knew about the huge influx of hundreds of Jewish immigrants since 1492 and the new experimentation with ghettos in Venice from 1516. Their sermons drew on intellectual exchanges between Jewish and Christian humanists, as Christian knowledge of Hebrew became standard intellectual training. Musso himself sometimes explained Hebrew words in his sermons to make an exegetical point. He explicitly linked rabbinic Jews to the newer antagonists facing the Church:

Newborn Jews absorb their paternal traditions with their milk, not those of Moses, which God wants them to read... but of their Talmuds, which never speak except against the Christian faith, and deprave sacred letters in their own way, no less than that which our heretics do in this miserable and calamitous era to the epistles of St Paul and the Gospels. ${ }^{73}$

\footnotetext{
${ }^{71}$ Diane Owen Hughes, 'Distinguishing Signs: Ear-Rings, Jews and Franciscan Rhetoric in the Italian Renaissance City’, Past \& Present, cxii (1986); Franco Mormando, The Preacher's Demons: Bernardino of Siena and the Social Underworld of Early Renaissance Italy (Chicago, 1999); Nirit Ben-Aryeh Debby, 'Jews and Judaism in the Rhetoric of Popular Preachers: The Florentine Sermons of Giovanni Dominici (1356-1419) and Bernardino Da Siena (1380-1444)', Jewish History xiv (2000); Roberto Rusconi, 'Predicatori ed ebrei nell'arte italiana del rinascimento', Iconographica III (2004); Jussi Hanska, 'Mendicant Preachers as Disseminators of Anti-Jewish Literary Topoi: The Case of Luca Da Bitonto', in Maria Giuseppina Muzzarelli (ed.,) From Words to Deeds: The Effectiveness of Preaching in the Late Middle Ages (Turnhout, 2014).

${ }^{72}$ For Bernardino on Jews, see Mormando, The Preacher's Demons, 164-218.

73 'Se dunque i Giudei à pena nati, col latte della nutrice succiano le paterne traditioni, non dico di Mosè, che Dio volesse lo leggessero, \& rileggessero sempre, che si accorgerebbono certo del loro errore, ma de' loro Talmuti, che non parlano mai, se non contra la fede Christiana, \& depravano le sacre lettere à modo loro, non meno di quello, che fanno i nostri Heretici à questa misera \& calamitosa età l'Epistole di San Paolo \& gli Evangeli.' Prediche Quadragesimali, II, 226.
} 
Yet all Musso's sermons avoid direct allusions to living Roman Jews. They even omit mention of Rome's new Monte di Pietà, founded in the very year Musso composed his sermons, and publicly preached during the same Lenten cycle of 1539. Musso was an especially careful editor of his own sermons, intending them to last for the ages. ${ }^{74}$ But even if he had removed local color from his sermons before printing them, any such references could only have been incidental, not extended passages central to the text. ${ }^{75}$ Musso's Jews are always an entirely imagined, hypothesized category, the eternal adversary or mirror of Christianity.

When Musso first preached these sermons in 1539, Roman concerns about Jews were in many ways still implicit. But during the decades of Musso's growing prestige, when he probably repeated them and tinkered with them every year, as popular preachers did, Papal attitudes towards Jews had developed into legislation. By the time the sermons were printed in two thick and heavily annotated volumes, conversionary procedures, both coercive and persuasive, had expanded enough to establish the conversionary pulpit that employed Marcellino and De Monte. The re-issuing of Musso's sermons throughout the rest of the century and beyond suggests their continuing relevance (even in their abstract language about Jews) to that new context. ${ }^{76}$

\section{Jews in Marcellino's other sermons}

Other preachers shared Musso's rhetorical approach to Jews. Marcellino also preached to Christians in a traditional manner, not only from his permanent post at Santa Maria in Aracoeli but also in elite churches throughout Rome and Italy. In those sermons he too

\footnotetext{
${ }^{74}$ Norman, Humanist Taste; John O’Malley, 'Form, Content and Influence of Works About Preaching Before Trent: The Franciscan Contribution', in I Frati Minori tra '400 e'500: Atti del XII convengno internazionale (Assisi, 1984).

${ }^{75}$ For the Monte di Pietà, see Wisch and Newbigin, Acting on Faith. For the difference between a spoken and a printed sermon in Early Modern Europe, see Stefano Dall'Aglio, 'Faithful to the Spoken Word: Sermons from Orality to Writing in Early Modern Italy', The Italianist xxxiv (2014).

${ }^{76}$ For a full list of Musso's publications, see Norman, Humanist Taste, 159-162.
} 
evoked Jews as a mirror of Christian behavior. In his commentary on the book of Ruth (a book in which Christians, incidentally, read Jewish conversion allegorically as the story of the true Church), Marcellino asked whether Elimelech, Ruth's father-in-law, was justified in going to Moab where he might fraternize with foreigners. Marcellino moved the action to Rome, berating a courtly culture too concerned with appearances, and advocating greater piety for a holy city:

And if he [Elimelech], who is partly excused... sinned by mixing with profane peoples, what about us, who converse all day with heretics, with Jews, and with stubborn sinners? Maybe we will argue that we do this in order to retrieve them from evil? I don't think we can say that, because they are more likely to convert us, than us them. We are wretched, then, who stay in the houses of sinners all day, and in the court of Princes, doing nothing but adoring, detracting, lying, feigning, scheming, and such... I admit that Rome is holy, the seat of Peter, and there are tombs of martyrs and the like, but with all this there is also much ambition, and many chances to depart from God, because here there is the seeing, and the being seen, the greeting, and the being greeted, the praising, the detracting... ${ }^{77}$

\footnotetext{
${ }_{77} \mathrm{E}$ se costui, che pure può essere in parte scusato... che peccasse accostandosi a genti profane, che sarà di noi, che con Eretici, con Giudei, e con ostinati peccatori tutto il dì conversiamo? Diremo forse di far questo acciò li ritiriamo dal male? Certamente non credo, che ciò possiam dire, atteso che più tosto essi convertano noi, che noi loro. Miseri adunque noi, che tutto il di stiamo per le case de peccatori, e per le corte de' Principi, altro non facendo che adulare, detrare, mentire, fingere, schernire, e simili...Io confesso dice san Girolamo... che Roma è Santa, \& è sedia di Pietro, e vi sono sepolcri de martiri, e simili, ma con tutto ciò ve anco molta ambizione, e molta occasione di partirsi da Dio, perche quivi il vedere, l'esser veduto: il salutare, l'esser salutato, il laudare, il detrarre, ...' Lezzioni Diciannove sopra Rut. del RPF Vangelista Marcellino de' Minori Osservanti. (Florence, 1586), 20r.
} 
Thus might a preacher invoke Jews to criticize his Roman listeners, and Marcellino, like Musso, often did. Marcellino's first commentary on the book of Daniel opens by describing the [ancient] Jews who listened to sermons as though to music, and continues:

And since it seems that you trust in hearing the word of God, and go filling the churches now after this preacher, and now after that one, I judge that this hearing of yours bears no more fruit than that of the Jews, because holy preaching is no more than a musical song in your eyes... and you listen much and do little. ${ }^{78}$

Howsoever Marcellino wanted to criticize his Christian listeners, whether for frantic social climbing, or indeed for frantic sermon-hopping, he likened them to Jews, capricious or stubborn as needed.

For both Musso and Marcellino, then, any references to living Jews were thickly veiled, even when the conversion of the Jews seemed paramount. Musso was deeply concerned with Jews, yet despite the example of his Franciscan predecessors, he still preached almost exclusively about the ahistorical Jews of Christian lore - even while emphasizing the need for their conversion. Marcellino's fame depended on preaching to Roman Jews, but his rhetoric always gave priority to an abstract Judaism rendered exemplary for Christians. The sermons in this brief sample all use the same language about Jews, despite the preachers' different concerns, styles, traditions, and audiences. A generic evocation of Jews was thus the norm in all styles of Christian sermons: Whether or not any Jews were listening, the word 'Jew' was given the same broad meaning - one that Christians could apply to themselves.

\footnotetext{
78 'e perche molto pare che ti confidi nel ascoltare la parola di Dio, e vai empiendo le chiese hora à questo predicatore, hora dietro à quello Io giudico che non piu fruttuoso habbia da esser il tuo udire, che fusse quello de Giudei, poiché la santa predicatione è nelle tue orecchie come un canto musicale, e come è altrimenti da che molto odi e poco fai.' Lettioni sopra daneiele Profeta del RPF Vangelista marcellino de Min. Osservanti. Fatte in Roma in Araceli (Venice, 1588), 3.
} 


\section{Conclusions}

Identifying the meanings attached to Judaism in early modern Rome helps us to appreciate both the significance and the popularity of conversionary preaching. First, in recognizing that conversionary preaching never addressed Jews exclusively or specifically, we see that this spectacle was not primarily intended to bring Jews to Catholicism. Roman clerics often knew that conversions were better won through persuasion and friendship than through derision and diatribes. Martin V, seeking to protect Jews from molestation, had censured the aggressive language of Observant mendicant preachers. ${ }^{79}$ Even promoters of conversionary preaching such as Filippo Neri took the same stance. Ippolito and Agostino Buoncompagni, born Ruben and Salomone Corcos, tell the story of being brought to the house of the Oratorians, where Neri gave sweets and figs to the 10-year-old Ruben, who in turn mistook him for the Pope. The next day, Neri met with the boys and made them a deal: they would all pray to 'the god of Abraham, Isaac, and Jacob' for illumination: if the Jewish law was right, Neri would convert to Judaism, but if the Christian law proved superior, he hoped they would convert instead. The boys' inevitable change of heart took place as Neri said Mass in the church while they waited in the library ${ }^{80}$ Neri's successor, Cesare Baronio, applied similar tactics to his much-celebrated efforts to convert both Roman Jews and foreign Protestants. He used a model of conversion based on close contact between individuals, the prominent celebration of baptisms, the promotion of successful neophytes, and the charismatic influence of the Catholic protagonist. ${ }^{81}$

Modern scholarship only confirms what Neri and Baronio knew: Conversion in the early modern period was frequently a gradual, fluid development, rather than a stark and

\footnotetext{
${ }^{79}$ Milano, Il ghetto di Roma, 47-49; Stow, Theater of Acculturation, 18-19.

${ }^{80}$ Incisa della Rocchetta and Vian, Il primo processo per San Filippo Neri nel codice Vaticano Latino 3798 e in altri esemplari dell'archivio dell'Oratorio di Roma I, 92-93. Testimony of Ippolito Buoncompagni, 26 Aug. 1595.

${ }^{81}$ Mazur, 'Searcher of Hearts’; Bianco, 'Cesare Baronio e la conversione dei Corcos'.
} 
sudden transformation. It was characterized both by tolerant dispositions on all sides and by porous boundaries between faith groups, allowing converts to maintain close ties to their birth communities. In Italy, unlike elsewhere in Europe, this model held true across denominations, class lines, and genders. ${ }^{82}$ Conversionary preaching, then, cannot be seen simply as a weapon in a crusade for Jewish souls.

Second, its reliance on Christian participation and its consistently cross-confessional language indicate another, more powerful function for conversionary preaching: to bring Christians to penitence. In these sermons, the primary element of persuasion addressed the back and sides of the Oratory, the Christian spectators, who could appreciate that conversionary preaching addressed them too. In their experience of listening to sermons, the word 'Jew' had always included them. At conversionary sermons, they heard the same language and lessons that had been preached to them in other churches, now reinforced by the sight of the Roman Jewish population brought in to display the possibility of penitence. Conversionary preaching may have been a crude tool for converting Jews, but it was a powerful new tool for converting Christian spectators, strengthening their distinct confessional identity in the much broader long-term mission of creating more committed Catholics. ${ }^{83}$

Whereas increasing scholarship on early modern exiles has shown that the presence of outsiders could confirm contested religious identities, and generate theories of tolerance, the

\footnotetext{
${ }^{82}$ See Ira Katznelson and Miri Rubin, Religious Conversion: History, Experience and Meaning, New edition (Farnham, 2014), 1-30, Peter A. Mazur, Conversion to Catholicism in Early Modern Italy (New York, 2016), and Andrew Pettegree, Reformation and the Culture of Persuasion (Cambridge, 2005). For converts from Protestant denominations, see Irene Polverini Fosi, Convertire lo straniero: forestieri e Inquisizione a Roma in età moderna (Rome, 2011). For Muslim converts, see Eric Dursteler, Renegade Women: Gender, Identity, and Boundaries in the Early Modern Mediterranean. (Baltimore, 2011). For a compelling example outside Italy, see Elisheva Carlebach, Divided Souls: Converts from Judaism in Germany, 1500-1750 (New Haven, 2001). ${ }^{83}$ Scholars of medieval Jewish-Christians have made a similar point. See Vose, Dominicans, Muslims and Jews in the Medieval Crown of Aragon, 74,135; 'Much medieval and Jewish polemical literature was highly effective and successful - not in convincing the out-group of the truth of the in-group's vision, but in convincing Christians of Christian truth and Jews of Jewish truth.' Chazan, Fashioning Jewish Identity in Medieval Western Christendom (Cambridge, 2004), 17.
} 
moment of the conversionary sermon suggests a different sort of interaction. ${ }^{84}$ In Rome, where Jews were 'intimate outsiders' of long standing, their own immediate concerns at the sermon were obscured, as was any social communion between them and other groups. ${ }^{85}$ Preachers did not acknowledge Rome's Jews directly, even though Rome housed the least easily ignored group of Jews in Europe. The role of Jews at conversionary sermons was to perform as universal, and thereby also Christian, version of themselves.

It is tempting to conclude here with a neat hypothesis that conversionary sermons aimed to convert Christians rather than Jews, but we must not do so. Seeing Jews as merely an ironical vehicle for the conversion of others tells an incomplete story. Conversionary sermons addressed Christians, to be sure, but through a spectacle that depended on both imaginary and living Jews. I contend, instead, that conversionary sermons were alluring and significant precisely because they allowed these boundaries to remain blurred. In the preaching spectacle, Jews could serve multiple, even contradictory, symbolic functions at once, simultaneously as potential new converts and as ancient Jews. In the late sixteenth century the recent zeal for turning Jews into Christians sat uncomfortably with older, still powerful concepts of Jews where the word 'Jew' was also a non-specific term that 'symbolizes all that was evil, dangerous and corrupt in the world. ${ }^{86}$ Conversionary fervor also jostled against the varied social or professional interactions Christians may have had with individual Roman Jews. ${ }^{87}$ For these reasons, conversionary sermons addressed Jews in multiple ways, as well as Christians, but to different extents and with different intentions.

${ }^{84}$ Timothy Fehler et al. (eds.), Religious Diaspora in Early Modern Europe: Strategies of Exile (London, 2014); Nicholas Terpstra, Religious Refugees in the Early Modern World: An Alternative History of the Reformation (Cambridge and New York, 2015).

${ }^{85}$ For the phrase, see Thomas V. Cohen, 'The Case of the Mysterious Coil of Rope: Street Life and Jewish Persona in Rome in the Middle of the Sixteenth Century', The Sixteenth Century Journal xix (1988).

${ }^{86}$ Debby, 'Jews and Judaism in the Rhetoric of Popular Preachers', 182. The phrase refers to Dominici's fifteenth-century theological construction of Jews.

${ }^{87}$ For an introduction to Jewish-Christian social interactions in Rome, see Lazar, Working in the Vineyard of the Lord; as well as Cohen, 'The Case of the Mysterious Coil of Rope'; Stow, Theater of Acculturation; Milano, Il ghetto di Roma; Anna Esposito, 'Gli ebrei a Roma tra Quattro e Cinquecento', Quaderni Storici vol. 18 (1983): 815-46; ibid., 'Pellegrini, stranieri, curiali ed ebrei a Roma', in. André Vauchez and Giulia Barone (eds.), Roma medievale, (Rome, 2001). 
On the one hand, therefore, the conversion of the Jews seemed more urgent than ever in the late sixteenth century. In light of the recent rupture of European Christendom, the antiquity of Jews - Roman Jews in particular - could remind pious Catholics that their own mission had always been incomplete. In this context, the persistent presence of unconverted Jews was newly problematic: it served as a lasting proof of the unfinished work of Catholicism, and the ever-present need to re-assert the supremacy of the Roman Church. ${ }^{88}$ Jewish conversion to Catholicism became the greatest endorsement of an embattled church, a prize worth pursuing energetically. Public conversionary sermons remained essential to this conversionary enterprise. Ideally, such sermons might even convert some Jews. But even if they did not, sermons remained critically useful for the conversionary enterprise in other ways. They allowed for the public display of neophytes, new catechumens, and potential converts as symbols of Catholic validation. More broadly, they could demonstrate publicly, to the pious and the curious alike, that the work of conversion, above all conversion by persuasion, was being done - to benefit not only Jews but also the entire city and Church.

At the same time, even Jews who refused conversion nonetheless contributed to a broader program of Catholic revival - directed not towards conversion, but towards triumphalism, proclaiming the continued vigour of the Church and the piety of its adherents. In this program, unconverted Jews continued to play their ancient role, defined by Augustine, of necessary witnesses who testified to the truth of Christianity. This role protected them from extermination, but also discredited any evolution or variation within Judaism. ${ }^{89}$ But as permanent outsiders, unconverted Jews also took on new roles especially relevant to a city obsessed with public piety. We have seen that sermons of both Musso and Marcellino, which appear at first to rehearse long-standing anti-Jewish tropes such as responsibility for the

\footnotetext{
${ }^{88}$ See also Magda Teter, Jews and Heretics in Catholic Poland: A Beleaguered Church in the Post-Reformation Era (Cambridge, 2006), 5.

${ }^{89}$ See above all Paula Fredriksen, Augustine and the Jews: A Christian Defense of Jews and Judaism (New York, 2008).
} 
crucifixion and perpetual stubbornness, also subtly reflect the particular concerns of their city: Jewish integration into Roman society, their contrast with Protestants, and their function as a mirror of impious behavior in Rome. The increased attention to piety and conformity that marked the Catholic Reformation suggests, too, why renewed attention to Jews in Rome came especially from new institutions, such as the Society of Jesus and the Congregation of the Oratory, and from prominent sites, such as San Lorenzo in Damaso and Santa Maria dell'Aracoeli, one on each side of the ghetto, that closely reflected the city's pride in itself.

Unconverted Jews served an especially useful purpose in a Reformation context. Recent Catholic polemics against Protestant innovation made a great virtue of Catholic antiquity, immutability, and steadfastness, in contrast with Protestant novelty and presumption. ${ }^{90}$ Such an approach benefitted from the ability to juxtapose untested Protestant upstarts with other antagonists and counterparts who, however mutable, at least had antiquity on their side. In this way, imaginary, unconverted Jews served a better rhetorical function for Catholics than did living Jews; they could be manipulated to fit a variety of arguments, and be portrayed as both worse than Protestants and better than Catholics, as necessary. Indeed, the very practice of using Jewish texts to refute Jewish theology tacitly acknowledged that Judaism was a worthy opponent. ${ }^{91}$ Preachers in Rome, and the Church they represented, needed Jews to remain outsiders, in part because for rhetorical purposes ancient Jews made better antagonists than arriviste Protestants.

For these reasons, any victories won by conversionary preaching were by definition limited. While the work of conversion became increasingly necessary, it could never be completed; both converted and unconverted Jews remained necessary to the validation of

\footnotetext{
${ }^{90}$ For one such polemic, see Ambrogio Catarino Politi, Compendio d'errori et inganni luterani (Rome, 1544). On Catholic anti-Lutheran polemics, see David V.N. Bagchi, Luther's Earliest Opponents: Catholic Controversialists, 1518-1525 (Minneapolis, 1991); Michelson, The Pulpit and the Press in Reformation Italy, 112-139.

${ }^{91}$ See Jonathan M. Elukin, Living Together, Living Apart: Rethinking Jewish-Christian Relations in the Middle Ages (Princeton, 2007).
} 
Catholicism in Tridentine Rome. As individuals, they could become acclaimed converts, while as symbols they could be held up as the truest mirrors of the pious. Jews were therefore not simply opponents but a multifaceted and contradictory theological symbol.

The unique situation of Jews in Rome, powerfully embodying the confluence of living and imaginary Jews, absorbed all these contradictory meanings. Elsewhere in Europe, where Jews were converted or exiled, the role of imaginary Jew fell to others. In post-expulsion Spain, conversos came to absorb Christian anti-Jewish rhetoric. ${ }^{92}$ In England, where only a few hundred Jews remained after the expulsion in 1290, the idea of Jewish conversion mirrored Englishmen's anxieties about their own religious identity. ${ }^{93}$ Yet in Rome, the native Jewish community filled that metaphoric role. One might even speculate that Jews were confined, rather than expelled or forcibly converted, because their deep Roman roots gave them added rhetorical usefulness at the heart of the newly global Catholic world.

The spectacle of conversionary preaching is uniquely potent because it brings all these threads about Jews together, slicing through the knotty question of which kind of Jew was more rhetorically useful in this period and how. Jews visibly on the brink of conversion could serve many opposing functions at once. In listening to conversionary sermons, they could be treated as both Christians and Jews, while as living Jews, they performed the role of imaginary Jews for the benefit of Christians. Whether they adopted Christianity or stubbornly rejected it, their presence affirmed the moral superiority of the Roman Church. Conversionary preaching even offered the opportunity for an act of 'horizontal confessionalization,' in which Jews, neophytes, tourists, and Catholic spectators helped to define each other's borders. ${ }^{94}$

\footnotetext{
${ }_{92}$ David Nirenberg, 'Mass Conversion and Genealogical Mentalities: Jews and Christians in Fifteenth-Century Spain', Past \& Present, clxxiv (2002).

${ }_{93}$ James Shapiro, Shakespeare and the Jews (New York, 1996); Jeffrey S. Shoulson, Fictions of Conversion: Jews, Christians, and Cultures of Change in Early Modern England (Philadelphia, 2013).

${ }^{94}$ For 'horizontal confessionalization', see Ute Lotz-Huemann, 'Confessionalization', in Alexandra Bamji, Geert H. Janssen, and Mary Laven (eds.), The Ashgate Research Companion to the Counter-Reformation, (Farnham, 2013), 50 .
} 
These various connotations were all plausibly linked not only in retrospect, but also for Christian congregants. As the anonymous diary confirms, conversionary sermons were simply a more exotic stop on a Christian sermon circuit that included many other pulpits. Avid sermon-goers could thus clearly witness the frequent linking of abstracted Jews and Catholic behavior, and the peculiar one of real and imagined Jews together, all within the explicit public spectacle that was Rome. Montaigne, Martin, the diary author, and the other Christians who went to watch Marcellino and his colleagues preach to Jews were drawn to the most potent symbol of the simultaneous success and failure of the Counter-Reformation. 